\title{
Aynur Ünal
}

PhD Candidate, University of Leicester, England

\section{Indigeneity Discourse within Kurdish Political Movement}

Abstract

This research looks at the indigenous, aspect of the Kurds and how indigenousness is expressed within the Kurdish political movement that has been paid limited attention. As this research addresses the differences between these two notions, it will be making a significant contribution on the indigenousness of Kurds that have been either widely seen as ethnic minority in the Middle East or their existence have been denied. I aim to draw scholarly attention to indigeneity discourse to address, in particular, the self-determination claim that is considered the most debated claim of indigenous peoples as self-determination, which is in the Kurdish context, one of the key demand of the Kurdish struggle is also defined as 'democratic autonomy/democratic confederalism' that was recognised by the United Nations in 2007 as one of the key rights of Indigenous Peoples.

Keywords: Indigeneity, Kurds, Middle East, Indigenous Peoples, Self-determination 


\section{Introduction}

This research aims to explore that to what extent indigeneity discourse is taken up and is expressed within the Kurdish political movement in Turkey. If so, it also looks at the significance of indigeneity discourse for Kurds and the other indigenous peoples of the Middle East in terms of recognition and self-determination rights. This in progress research has been conducted through documentary analysis and semi-structured interviews. Whilst documentary analysis concentrated on party rules, programs and statements of the two latest pro-Kurdish political parties that include Peace and Democracy Party (BDP) and Peoples' Democracy Party (HDP) between 2009 and 2017, semi-structured interviews were conducted with twenty parliamentary ministers of HDP. The study has been carried out to explore indigenous aspect of Kurds by focusing on the main themes of indigeneity that include self-identification, language, culture, histori$\mathrm{cal} /$ spiritual bond to ancestral land and self-determination.

\section{Differentiation between Indigeneity and Ethnicity Concepts}

A considerable amount of study has been carried out on the concept of indigeneity, and indigenous peoples that have been defined by various terms, including Aboriginals, Native Peoples, First Nations, and Fourth World people (Šavelková 2011). Their global population is approximately 350 million, and they live in more than 70 different countries divided into 5,000 peoples. Asia is the most indigenously populated continent, and is home to $70-80 \%$ of the world's indigenous peoples (International Labour Organization 1989). Scholars have also drawn attention to between ethnicity and indigeneity concepts. As the dictionary definition of these concepts follows:

Indigenous: originating or occurring naturally in a place; native.

Ethnicity: the fact or state of belonging to a social group that has a common national or cultural tradition.

Autochthonous: (of an inhabitant of a place) indigenous rather than descended from migrants or colonists (Oxford Dictionaries 2017).

Olaf Zenker (2011) points out that two concepts, indigeneity and autochthony, are closely interrelated and both involve a common culture, language, history, and sense of 
belonging to the land, and thus are expanded definitions of ethnicity. Therefore, the significance made through the global indigenous rights movement in the differentiation between indigeneity and ethnicity that "paved the way for Indigenous Peoples to refuse to be considered simply as ethnic minorities within a nation-state" (Weaver 2008, p. 231).

On the other hand, whilst the general frame of the concept of indigeneity maintains its divergence in the African and Asian contexts (Kingsbury 1998), the indigenous peoples of the Middle East are more complicated and have not been even given proper attention. Mohamad G. Alkadry (2002) argues that the deliberate practice of undermining the notion of indigenous people of the Middle East led to the emergence of artificial nation-states, which in turn created challenges for the democratisation process of the region. In contrast to the oriental image of the Middle East propagated by the West, which stereotypes the peoples and cultures of the region as backward and mystic, the Middle East is very diverse. Only one indigenous community has appeared within in the international arena through the International Work Group for Indigenous Affairs (IWGIA)'s 2017 annual report, the Middle East has only one indigenous community, the Bedouin, divided into those living in Israeli-occupied territories and those in Palestine (IWGIA 2018).

It is interesting enough that whist the history of the Kurds in the region dates to around 8,000 years ago with the settlement of the Halaf culture in the Kurdish mountains (Izady 1991), one question that needs to be asked, however, why Kurds have not been indigenous peoples of the region. In order to strengthen my argument on definition and rights of indigenous peoples, I will provide further information on the international law aspect to indigenous peoples.

\section{Recognition of Indigenous Peoples within International Institutions}

The indigenous rights movement and attention to indigenous peoples have been of interest not only to academics but also other parties, including the ILO, the World Bank, the World Council of Indigenous Peoples (WCIP), and the IWGIA (Šavelková 2011; Gomes 2013; Graham, Penny 2014). The ILO was the first international organisation to address indigenous issues. The first convention of the ILO occurred in 1957 and was

\footnotetext{
1 The IWGIA was founded (and is still operated) by Danish anthropologists in 1968, making it the earliest indigenous rights advocacy NGO in the Western world.
} 
entitled ILO Convention 107: Concerning the Protection and Integration of Indigenous and Other Tribal and Semi-Tribal Populations in Independent Countries. It addressed indigenous peoples as 'tribal or semi-tribal population[s]' (Fodella 2006). On the other hand, there was a significant shift in 1989, at which point the ILO adopted the Indigenous and Tribal Peoples Convention 169, which came into force in 1991 after being ratified by only 22 countries (International Labour Organization 1989). According to Article 1:

1. This Convention applies to:

(b)??? peoples in independent countries who are regarded as indigenous on account of their descent from the populations which inhabited the country, or a geographical region to which the country belongs, at the time of conquest or colonisation or the establishment of present state boundaries and who, irrespective of their legal status, retain some or all of their own social, economic, cultural and political institutions.

2. Self-identification as indigenous or tribal shall be regarded as a fundamental criterion for determining the groups to which the provisions of this Convention apply.

There are also some scholarly definitions of indigenous peoples that support the perspective of the ILO. For example, Barnard (2004, p. 19) claims that "the acceptable point about the classification of peoples as 'indigenous' is not that they pre-date other people, but that they pre-date state formations established to protect such other peoples".

Another major development in the indigenous rights occurred in 2007 the United Nations by adoption of the United Nations Declaration on the Rights of Indigenous Peoples (UNDRIP). The direct relation between the definition of indigeneity and indigenous rights led to the emergence of a variety of perspectives because of the political aspect of 'indigenousness'. The diversity of indigenous nations is considered a reason for the absence of an official definition of indigenous peoples within international law, to avoid the exclusion of any groups in different parts of the world (Marlow 2016).

Apart from those fundamental rights, the UNDRIP includes one of the most controversial aspects of indigenous rights, self-determination, in Article 3:

Indigenous peoples have the right to self-determination. By virtue of that right they freely determine their political status and freely pursue their economic, social and cultural development (United Nations 2017).

The consensus view seems that 'self- determination' claim is the most disputable piece of indigenous rights. On the ground, states have still the most privilege position on indigenous issues in light of the non-binding nature of the UNDRIP. Although they 
claim self-determination, land, and cultural rights, it does not necessarily mean that they all aim to gain political separation. The bottom line of their struggle is to obtain recognition as "distinctive members with special rights" (Weaver 2008, p. 231). The international law clearly identifies the difference between ethnic minority rights and indigenous rights. As the ethnic minorities rights, recognition of their existence, right to have nondiscriminatory multiculral/intercultural education and equal opportunity to participate in every aspect of society, indigenous rights recognize all the the rights of ethnic minutes and self-determination right and right to access to and control over their natural resources.

When indigenous peoples and, in particular, indigenous scholars have become actual actors in indigeneity matters, second-wave indigeneity ${ }^{2}$ began to emerge as a further step of recognition, one which involves claiming the right of self-determination such as in the case of the Zapatista movement in $\mathrm{Mexico}^{3}$ (The Politics of Indigeneity Dialogues and Reflections on Indigenous Activism 2012). This view is supported by Reyes and Kaufman (2011), who claimed that the "Zapatismo innovated conceptions of indigeneity and autonomy" (p. 521) outside of, suggested neoliberal options, such as complying with the state government. In recent years, studies on the Zapatista movement have led to transnational comparative studies on armed struggles with states. One distinguished example of research in this area is the work of Zeynep Gambetti (2009), who has conducted comparative research on the Zapatista and Kurdish movements based on two particular places, Chiapas in Mexico and Diyarbakir in the Kurdistan Region of Turkey.

\section{Kurdish Political Movement}

The recent development of literature on Kurdish studies has emerged with the reawakening of the Kurdish movement, which was led by Kurdish higher education students in the metropolises of Ankara and Istanbul (Bengio 2014). As part of the regional political escalation, particularly in the last decade, the literature on Kurdishness has also

\footnotetext{
2 The increasing role of indigenous scholars and activists in indigenous matters and emerging political struggles has been identified as 'second-wave indigeneity' in The Politics of Indigeneity Dialogues and Reflections on Indigenous Activism 2011.

${ }^{3}$ In 1994, the indigenous Zapatista Army of the National Liberation (Ejército Zapatista de Liberación Nacional, EZLN) declared war on Mexican state and took over seven municipalities in the state of Chiapas in southern Mexico.
} 
been expanding significantly. A variety of disciplines, including political, cultural, diasporic, and sociological studies, address the issues facing Kurds in the Middle East. Scholars from contemporary social sciences have primarily concentrated on political history and the relationships between the nation-state and Kurds in the region. Significant improvement in Kurdish cultural publications in the 1960s built strong relationships with the Turkish left, and they also created a platform on which discussions were held on Kurdish identity (Yavuz 1998; Sheyholislami 2011) and the underdevelopment of the Kurdish region (Beşikçi 2004).

Kurds form a distinct nation within their various states (Turkey, Iraq, Iran, and Syria), and they have their own language, customs, traditions, and history in relation to the region known as Kurdistan, and have experienced oppression, denial of their identity, assimilation policies, and marginalisation (Houston 2009). The region of Kurdistan being subsumed within the borders of Turkey, Iran, Iraq, and Syria, and smaller parts in Armenia and Azerbaijan and those "ethnically-based nationalist regimes - Turkish, Arabs and Persians - [had] little or no tolerance for expressions within their borders of national autonomy" (Hassanpour 1994, p. 3). Kurds have nevertheless maintained their identity and have considered their homeland Kurdistan since the $7^{\text {th }}$ century.

Kurds speak various languages and dialects. There is often an erroneous assumption that they descend from other nations Persians/Iranian and that assumption is what Hennerbichler is arguing against. Ferdinand Hennerbichler (2012) suggests that the ancestors of the Kurds in the region had a different cultural, ethnic, linguistic, and genetic structure to the Iranians. The people of Kurdistan have maintained their culture, language, and identity not only in Iran also other in the other countries although they have faced oppression, marginalisation, assimilation, and forced migration. As a result of state politics in countries that have the most significant Kurdish populations, in particular Turkey, Kurdish people have been forced to migrate internally and internationally over many years. The reason stems from political and economic factors that have been impactful since the early twentieth century (Wahlbeck 2002).

The literature on the Kurds also indicates that the Kurdish self-rule system and Kurdish nationalism were constructed between the fifteenth and nineteenth centuries, and shows that Kurdish nationalism was even identified in Ahmad Khani's classic story Mem $\hat{u}$ Zin (Mam and Zin) three hundred years ago (Hassanpour 1993), which is seventeenth century epic of Kurdish literature is a love story of Mem and Zin who separated. 
However, it is also considered the symbol of separation of Kurdish nation by its neighbours (Galip 2015).

Historical facts and figures of Kurds in the region indicate that the Kurds are more than an ethnic minority within those four states. Taken collectively, on a global scale, the Kurds are one of the largest nations without a nation-state, currently with minimum estimated 36,6 million Kurds spread out over Iran, Iraq, Syria, and Turkey and the total Kurdish diaspora population living overseas is approximately 1.5 million (Kurdish Institute of Paris 2017).

Figure 1 has also been provided to illustrate the data provided above as referred Kurdistan that is accepted the historical land of Kurds.

Figure 1. The map of areas of majority Kurdish settlement, Kurdistan

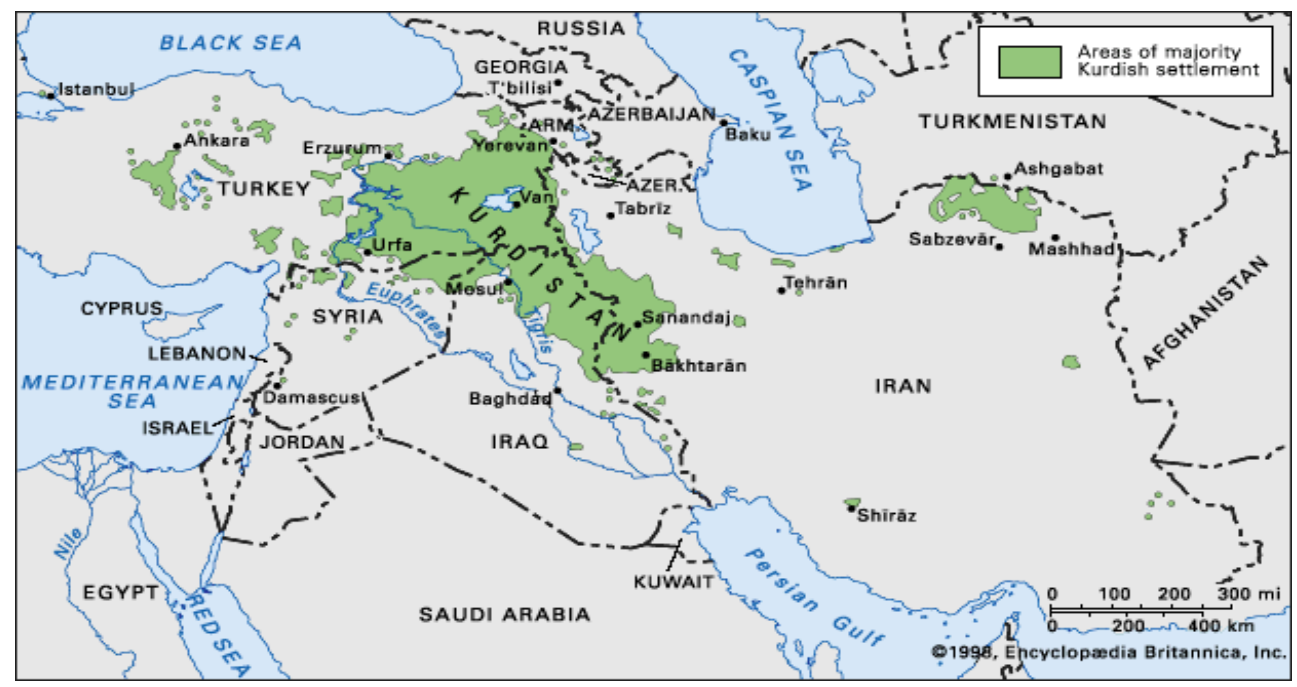

Source: Encyclopaedia Britannica (2018).

The Kurdish movement in the region has been influenced and shaped by its host states, which have also influenced each other. Kurds in Iraq and Iran established the Kurdistan Democratic Party (KDP) in 1945 and the Patriotic Union of Kurdistan 
(PUK) in 1975 (Hassanpour 1994). Although Kurds in Syria has made a significant impact on fighting terrorists in the last couple of years, their identity, their language, even citizenship rights were denied and oppressed by the Syrian state.

On the other hand, the history of the Kurdish political movement or Kurdish struggle in Turkey goes back to before the establishment of the Turkish Republic. Even so, if one examines the era of the Ottoman Empire, one can certainly question how visible a discussion on the interaction of the populations regarding an indigenous rights movement would have been (Hassanpour 1994). The Kurdish political movement in Turkey appeared, or better yet "reappeared after [the] Sheikh Said Rebellion [in] 1925, Mount Ararat [in] 1930, and [the] Dersim 1938 rebellions" (Gunes 2007, p. 17), and also in the late 1950s and 1960s. ${ }^{4}$ The Republic of Turkey was established as a nation-state in 1923 and with this change the existence of the Kurds was denied: "From [the] mid-1920s until the end of the 1980s, the Turkish state 'assumed' that there was no Kurdish element on Turkish territory" (Yeğen 1996, p. 216).

The late 1960s and 1970s were critical regarding the creation of mass political involvement, and it was during these decades that many leftist Kurdish parties were born. Apart from various Kurdish political parties, the Partiya Karkêren Kurdistan (Kurdistan Workers' Party, or PKK) emerged as a political party with a Marxist-Leninist ideological structure in 1978 (Casier 2010). The PKK also developed a grassroots/bottom-up governance model that is described as "democratic autonomy and democratic confederalism” (Jongerden 2015, p. 4), which is "a participatory-democratic form of politics, based on active citizenship" (p. 4).

This model resembles the practices of the Ejército Zapatista de Liberación Nacional (Zapatista Army of National Liberation; EZLN) in Mexico (Jongerden 2015), as will be discussed in more detail later in this report. Since then, the PKK has become a crucial party both in the Kurdish movement and Kurdish literature, and also in social and political sciences and Turkish studies. However, as Marlies Casier and Joost Jongerden (2012, p. 3) note, most of the academic literature on the PKK does not attempt to

\footnotetext{
${ }^{4}$ The Sheikh Said rebellion occurred in 1925 and lasted for about 3 months in the Kurdish region of Turkey: particularly Bingöl, Palu, Genç, Diyarbakır and Varto. The Ararat rebellion, also known as the Ağrı rebellion, was an uprising of the Kurdish residents of the province of Ağn in eastern Turkey against the Turkish government that took place in 1930. Dersim (Eastern Turkey and part of Kurdistan and currently known as Tunceli province) rebellion emerged in 1937-38 and was supressed by the Turkish military operation that caused thousands of people's life and forced migration.
} 
understand the movement but tries to show the PKK as an expression of something else. Unsurprisingly, a significant part of the academic literature on the PKK is written from the perspective of criminology.

However, the clashes between the Turkish state and the PKK have had their ups and downs. Although there have been two serious attempts at a ceasefire, in 1993 and 2009, no solution has been reached yet. Dramatic political changes in Turkey since the Gezi protest in 2013 have led to a collapse of the ceasefire period that was agreed between the Turkish state and the PKK in 2009, which is also referred as the 'Kurdish Opening' in 2009 which started collapsing in 2012 (Gunter 2013; Baser 2016).

However, all Kurdish political parties that appeared from the 1990s until 2015 were unable to survive due to Turkish state politics. The chronological order of pro-Kurdish political parties in Turkey is presented below.

Table 1. Chronological order of pro-Kurdish political parties in Turkey (1990s - present)

\begin{tabular}{llll}
\hline Abbreviations & Party Title & Date Founded & Date Closed \\
\hline HEP & People's Labour Party & 7 June, 1990 & 14 July, 1993 \\
\hline ÖZEP & Freedom and Equality Party & 25 June, 1992 & Merged with HEP, 1992 \\
\hline DEP & Democracy Party & 21 June, 1991 & 16 June, 1994 \\
\hline OZDEP & Freedom and Democracy Party & 19 October, 1992 & 23 November, 1993 \\
\hline HADEP & People's Democracy Party & 11 May, 1994 & 13 March, 2003 \\
\hline DEHAP & Democratic People's Party & 24 October, 1997 & 19 November, 2005 \\
\hline DTP & Democratic Society Party & 9 November, 2005 & 11 December, 2009 \\
\hline BDP & Peace and Democracy Party & 2 May, 2008 & 22 April, 2014 (merged with HDP) \\
\hline HDP & People's Democratic Party & 15 October, 2012 & Presently active \\
\hline
\end{tabular}

Source: HDP Europe 2017.

With the exception of the HDP, all of these parties did not manage to get elected due to the election threshold of the Turkish system. Some of them have closed down, and many of their members detained and some of them banned from future political activity. However, in 2015 the HDP, managed to get into the Turkish parliament for the first time. 
The most recent academic perspective on Kurdish affairs is divided into two core groups. Political studies discuss the PKK and Kurdish nationalism as forms of separatism through the politics of states. However, there is also a significant development in studies concerning Kurdish political and cultural rights from the perspective of critical social sciences. These involve examining the ideological and theoretical background of the Kurdish political movement, particularly the ideology of "democratic autonomy or democratic confederalism" (Jongerden 2015, p. 4). That captures the ideological shift of the PKK in 1999 along with the desire to go from "national independence to a form of autonomy" within Turkey (Leezenberg 2016). Nevertheless, the end of the 1990s marked a turning point for the Kurdish movement for two primary reasons. The first was the capture of the leader of the PKK, Abdullah Ocalan, and the second was the result of the EU negotiation process concerning emerging Kurdish political parties (Balci 2015). Despite the military coup of 1980 and Ocalan's capture, the PKK has still maintained a significant level of support (Gunes 2007). Democratic autonomy and confederalism are "a participatory-democratic form of politics, based on active citizenship" (Jongerden 2015, p. 4). Although this bottom-up model was developed by the PKK in Kurdistan, the resemblances to the practices of the Zapatista movement in Mexico are significant (Jongerden 2015).

Studies on Kurds and Kurdish issues have primarily concentrated on violence in the Kurdish movement, either by explaining the movement through the impact of Turkish state politics (Bozarslan 2000) or criticising the violence and studying it as terrorism (Criss 1995).

A striking point is that there has not been enough scholarly attention given to the indigenous aspect of Kurds in the Middle East. Although there is a convincing resemblance between indigenous rights movements and the Kurdish movement, indigenous literature has not recognised Kurds as indigenous, and nor has a considerable proportion of the extant literature on Kurds included an indigenous aspect. Instead, it has been studied under the umbrella of a "social movement", specifically what is known as the "Kurdish movement" (Balci 2015), and recently as the "Kurdish political movement or activism" (Gunes 2007) or the "Kurdish issue or struggle" (Gambetti, Jongerden 2011; Casier, Jongerden 2012). 


\section{Conclusion and Preliminary Findings}

It is undeniable that the concept of indigeneity and indigenous peoples is still one of the disputed subjects to academia. However, considerable amount of conducted study indicates that significant difference between ethnicity and indigeneity that significantly address the right of self-determination of indigenous peoples.

This study has aimed to draw attention the indigenous aspect of Kurds by exploring through self-identification within Kurdish political movement in Turkey. The preliminary findings of the research indicate that the participants of the Kurdish political movement refuse the ethnic minority discourse of Kurds and described them/selves as one of the 'kadim' - autochthonous ${ }^{5}$ peoples of Mesopotamia, which is not only of Turkey also Syria, Iraq and Iran and see Kurds as primary component/constitutive element ${ }^{6}$ of the Turkish state. They also state that main demands of Kurdish political movement that include equal citizenship, recognition, education in mother language and self-determination rights are the demands of grass root since the establishing of Turkish state. Another significant finding is the description of Kurdistan as a historical/ancestral land of Kurds. The findings also shows the development of self-determination claim of Kurds and suggests 'democratic condeferalism' as self-determination claim can be solution for not only peoples from different ethnic backgrounds in Turkey but also for long lasting ongoing the chaos of the Middle East where nation states were established by denying of existence of peoples from different ethnic backgrounds.

\section{References}

Alkadry M.G. (2002), Reciting Colonial Scripts: Colonialism, Globalisation and Democracy in the Decolonized Middle East, "Administrative Theory \& Praxis" Vol. 24, No. 4

Balci A. (2015), The Kurdish movement's EU policy in Turkey: An analysis of a dissident ethnic bloc's foreign policy,

"Ethnicities" Vol. 15, No. 1

\footnotetext{
${ }^{5}$ The most used word was to define indigenousness is 'kadim' that means autochthonous, very old, ancient etc.

${ }^{6}$ This is the significant word, 'asl-i unsur' that means primary component/primary constitute element that was used by the participants of the research to claim that Kurds were previously promised as the other main party with Turks in the foundation of Turkish Republic in 1923.
} 
Barnard A. (2004), Indigenous Peoples: A Response to Justin Kenrick and Jerome Lewis (AT20[2]), "Anthropology Today", Vol. 20, No. 5

Baser B. (2016), Diasporas and Homeland Conflicts: A Comparative Perspective, Routledge, London

Bengio O. (2014), Kurdish Awakening: Nation Building in a Fragmented Homeland, University of Texas Press, Austin

Beşikçi I. (2004), International Colony Kurdistan, Taderon Press, Parvana

Bozarslan H. (2000), Why the armed Struggle? Understanding the Violence in Kurdistan of Turkey, (in:) The Kurdish Conflict in Turkey: Obstacles and Chances for Peace and Democracy, (eds.) Ibrahim F., Gürbey G, , LIT Verlag, Münster

Casier M., Jongerden J. (2012), Understanding today's Kurdish movement: Leftist heritage, martyrdom, democracy and gender, "European Journal of Turkish Studies" Vol. 14

Casier M. (2010), Designated Terrorists: The Kurdistan Workers' Party and its Struggle to (Re) Gain Political Legitimacy, "Mediterranean Politics" Vol. 15, No. 3

Criss N.B. (1995), The nature of PKK terrorism in Turkey, "Studies in Conflict \& Terrorism" Vol. 18, No. 7

Encyclopaedia Britannica (2018), Kurd - people, Kurdish settlement - Areas of Kurdish settlement in Southwest Asia, https://www.britannica.com/topic/Kurd

Fodella A. (2006), International Law and The Diversity of Indigenous Peoples, "Vermont Law Review", Vol. 30, No. 565

Galip O.B. (2015), Imagining Kurdistan: Identity, Culture and Society, I.B.Tauris, New York

Gambetti Z. (2009), Politics of place/space: The spatial dynamics of the Kurdish and Zapatista movements, "New Perspectives on Turkey" Vol. 41

Gambetti Z., Jongerden J. (2011), The spatial (re)production of the Kurdish issue: multiple and contradicting trajectories-introduction, "Journal of Balkan and Near Eastern Studies", Vol. 13, No. 4

Gomes A. (2013), Anthropology and the Politics of Indigeneity, "Anthropological Forum" Vol. 23, No. 1

Graham L.R., Penny H.G. (2014), Performing Indigeneity: Global Histories and Contemporary Experiences, University of Nebraska Press, Lincoln

Gunes C. (2007), Kurdish politics in Turkey: "a question of identity", "International Journal of Kurdish Studies" Vol. 21, Nos. 1-2

Gunter M. (2013), Reopening Turkey's Closed Kurdish Opening?, "Middle East Policy", Vol. 20, No. 2

Hassanpour A. (1994), The Kurdish Experience, "Middle East Report", Vol. 24, No. 189

HDP Europe (2017), History of Kurdish political parties in Turkey, http://en.hdpeurope.com/?page_id=537

Hennerbichler F. (2012), The Origin of Kurds, "Advances in Anthropology”, Vol. 2, No. 2

Houston C. (2009), An Anti-History of a Non-People: Kurds, Colonialism, and Nationalism in the History of Anthropology, "The Journal of the Royal Anthropological Institute", Vol. 15, No. 1

International Labour Organization (1989), C169 - Indigenous and Tribal Peoples Convention, No. 169, http://www.ilo.org/dyn/normlex/en/f?p=NORMLEXPUB:12100:0::NO::P12100_INSTRU-

MENT_ID:312314 [01.12.2016] 
IWGIA (2018), IWGLA. Business Registration No. 812944 10. Annual report 2017, https://www.iwgia.org/images/documents/IWGIA-Annual-Report-2017-002.pdf

Izady M.A.,(2009), The Kurds: A Concise History And Fact Book, Taylor \& Francis, New York

Jongerden J. (2015), Radicalising Democracy: Power, Politics, People and the PKK, "Centre for Policy and Research on Turkey (Research Turkey)" Vol. 4, No. 3

Kingsbury B. (1998), Indigenous Peoples in International Law: A Constructivist Approach to the Asian Controversy, "The American Journal of International Law" Vol. 92, No. 3

Kurdish Institute of Paris (2017), The Kurdish population, https://www.institutkurde.org/en/info/the-kurdish-population-1232551004 [20.04.2017]

Leezenberg M. (2016), The ambiguities of democratic autonomy: the Kurdish movement in Turkey and Rojava, "Southeast European and Black Sea Studies" Vol. 16, No. 4

Marlow K. (2016), UN Declaration on the Rights of Indigenous Peoples: who is it for?, http://www.sbs.com.au/ nitv/article/2016/09/13/un-declaration-rights-indigenous-peoples-who-it [26.03. 2017]

Oxford Dictionaries (2017), https://en.oxforddictionaries.com/definition/autochthony

Reyes A., Kaufman M. (2011), Sovereignty, Indigeneity, Territory: Zapatista Autonomy and the New Practices of Decolonization, "South Atlantic Quarterly" Vol. 110, No. 2

The Politics of Indigeneity Dialogues and Reflections on Indigenous Activism (2011), (eds.) Venkateswar S., Hughes E, Zed Books, London

Sheyholislami J. (2011), Kurdish Identity, Discourse, And New Media, Palgrave Macmillan, New York

Šavelková L. (2011), Indigenous Peoples - Creating New "Borderlines"?, "Indigenous America - América Indígena" Vol. 4, No. 2

United Nations (2017), Declaration on the rights of indigenous peoples, Human Rights Commission, http://www. ohchr.org/EN/Issues/IPeoples/Pages/Declaration.aspx [26.03.2017]

Wahlbeck Ö. (2002), The concept of diaspora as an analytical tool in the study of refugee communities, "Journal of Ethnic and Migration Studies", Vol. 28, No. 2

Weaver J (2008), Indigenousness and Indigeneity, (in:) A Companion to Postcolonial Studies, (eds.) Schwarz H., Ray, S., Oxford, Blackwell Publishing

Yavuz M.Y. (2007), A preamble to the Kurdish question: the politics of Kurdish identity, "Journal of Muslim Minority Affairs" Vol. 18, No. 1

Yeğen M. (1996), The Turkish state discourse and the exclusion of Kurdish identity, "Middle Eastern Studies" Vol. 32 , No. 2

Zenker O. (2011), Autochthony, ethnicity, indigeneity and nationalism: Time-honouring and state-oriented modes of rooting individual - territory - group triads in a globalizing world, "Critique of Anthropology" Vol. 31, No. 1 